\title{
Quality assessment of compost prepared from spent mushroom substrate
}

\author{
R Ashrafi ${ }^{1 *}$, MM Rahman ${ }^{2}$, M Jahiruddin ${ }^{2}$, MH Mian ${ }^{2}$ \\ ${ }^{1}$ Horticulture Division, Bangladesh Institute of Nuclear Agriculture, Mymensingh 2202, Bangladesh \\ ${ }^{2}$ Department of Soil Science, Bangladesh Agricultural University, Mymensingh 2202, Bangladesh
}

\begin{abstract}
Disposal of spent mushroom substrate (SMS) generated by the mushroom production industry has an adverse effect on the environment which leads to a deterioration of soil, air and water quality. Scope exists to use this substrate to produce good quality compost. The present study was done to assess the quality of SMS compost through evaluation of their characteristics and the chemical changes that occur during composting. Physical, chemical and microbial characteristics were determined by observing color, moisture (\%), size reduction, weight loss, pH, EC, different nutrient contents and abundance of E. coli and Salmonella spp. The result showed an increasing trend for the $\mathrm{pH}, \mathrm{N}, \mathrm{P} \& \mathrm{~S}$ concentration and a decreasing trend for EC, OC \& C/N ratio during composting period. As determined, the $\mathrm{pH}$ value (7.38) and the $\mathrm{C} / \mathrm{N}$ ratio (21) were within the recommended range that used in different countries. The concentrations of N, P, K, S, Ca, Mg, Fe, Mn \& B were measured as $1.17 \%, 0.08 \%, 1.04 \%, 0.11 \%, 2.76 \%, 0.43 \%, 0.51 \%, 0.03 \%$ and $0.01 \%$, respectively, all of which were within the recommendation limits. Heavy metals such as $\mathrm{Zn}, \mathrm{Cu}$ and $\mathrm{Ni}$ contents were recorded as $0.007 \%, 0.001 \%$, and $0.33 \mathrm{ppm}$, respectively showing their values within the maximum allowable limits. The concentration of $\mathrm{Pb}$ and $\mathrm{Cd}$ was below the detection limit. The SMS compost was free of E. coli and Salmonella spp. Hence, all these properties indicate that the SMS can be effectively used to produce good quality compost.
\end{abstract}

Key words: Spent mushroom substrate, composting, heavy metals

Progressive Agriculturists. All rights reserve

*Corresponding Author: reema_ashrafi@yahoo.com

\section{Introduction}

The human demand for protein-rich food is everincreasing which contributes to the expansion of mushroom industry in the world. Statistically, the word production of mushroom industry has reached a level greater than 25 million tons (Yang et al., 2015). In spite of many advantages, the production of mushrooms generates large volumes of solid waste products (called spent mushroom substrate) which constitute one of the most significant environmental issues for the mushroom industry (Topas et al., 2014) as about $5 \mathrm{~kg}$ of waste substrates are generated from the production of $1 \mathrm{~kg}$ of mushrooms (Medina et al., 2012).

At present, the management of organic waste is a major concern worldwide, as unscientific disposal of waste can adversely affect the environment. Inadequate management of waste leads to problems that impair human and animal health. It leads to land pollution if openly dumped, water pollution if dumped in low lands and air pollution if burnt (Hai and Ali, 2005). The open dumped sites of organic waste act as breeding ground for various disease vectors.

The waste disposal problems can be reduced by waste minimization, reuse and recycling of its components and converting the organic components of the waste into a valuable product and reused without adversely affecting the environment (Fathi et al., 2014). Composting is an economic and sustainable option for organic waste management as it is comparatively easy to manage properly to produce a good quality product. It is a technique which facilities mass reduction of waste resulting in its stabilization (Nair et al., 2006). 
A wide range of physico-chemical and biochemical changes occurs during composting (Irshad et al., 2013). It has a significant value to provide further information regarding the nutritional and toxicity status of manure amendments. Compost prepared from different organic wastes differ in their quality and stability, which further depends upon the composition of raw material used for the compost production (Ranalli et al., 2001). Proper characterization of the compost is necessary to predict potential beneficial and harmful effects of compost applications in the environment. Understanding the composting processes and compost characteristics also allows optimal design of compost amendments and allows for decomposing the organic materials into a more compact form for management. The present study aimed at examining the physical, chemical and biological characteristics including heavy metals concentration at different stages of SMS composting and hence to determine their quality as a good compost.

\section{Materials and Methods}

\section{Preparation and production of compost using spent mushroom substrate}

Composting was done at the Field Laboratory of the Department of Soil Science, BAU, Mymensingh during April to July 2010. Spent mushroom substrate (SMS) was collected and then separated from the polythene bag, broken by hammer and heaped into piles over a 12-week period. The size of compost pile was $5 \mathrm{ft} \times 2 \mathrm{ft} \times 3 \mathrm{ft}$ (length $\times$ width $\times$ height). Compost pile was constructed by maintaining a layer of 8 inch height. Cowdung and grasses were applied between 2 layers for rapid composting. The composting materials were turned at 15-day intervals over 12 weeks period and kept 1 month for curing. Compost samples were collected from the pile at prefixed time that means just after mixing of the materials (start of composting process) and after 4, 6, 8, 10 and 12 weeks of composting. Samples were dried in an oven at $60^{\circ} \mathrm{C}$, ground and sieved by $1-\mathrm{mm}$ sieve and then analyzed to monitor the changes in physical, chemical and biological properties.

\section{Phytotoxicity test}

Phytotoxicity test was performed with radish seeds. This test was conducted by sowing radish seed in earthen pots containing three types of soil-compost mixtures i.e. $100 \%$ soil, $100 \%$ compost and compost with soil 1:1 ratio. After germination of seed, seedlings were allowed to grow for 10 days and then uprooted carefully to observe whether any toxic symptoms were shown on the shoots and roots of the seedlings.

\section{Characterization of mature compost}

Following active composting method, the composted material was allowed for curing over a minimum of one month to create more stable compost and to reduce the potential for plant phytotoxicity. Then the spent mushroom compost was sampled to measure physical, chemical and biological characteristics. Compost color and compost odor were observed. Moisture percentage was determined by weighing SMS compost before and after oven drying. Size reduction and weight loss percentage were measured by measuring size and weight at the beginning and end of composting. $\mathrm{pH}$ was determined by Corning glass electrode $\mathrm{pH}$ meter (Jackson, 1973). The samples were analyzed after digestion with sulphuric acid for the determination of $\mathrm{N}$ and with nitricperchloric acid for other nutrients. Nitrogen in the digest was estimated by distilling the digest with $10 \mathrm{~N}$ $\mathrm{NaOH}$ followed by titration of the distillate trapped in $\mathrm{H}_{3} \mathrm{BO}_{3}$ indicator solution with $0.01 \mathrm{~N} \mathrm{H}_{2} \mathrm{SO}_{4}$ (Page et al., 1982). Organic carbon was measured by dry combustion method. Phosphorus and boron was determined by spectrophotometric molybdovanadate method (Yoshida et al., 1976) and the S concentration by turbidity method (Chapman and Pratt, 1964). The K concentration in the acid digest was determined directly by flame photometer and other nutrients viz. $\mathrm{Ca}, \mathrm{Mg}, \mathrm{Cu}, \mathrm{Fe}, \mathrm{Zn}, \mathrm{Mn}, \mathrm{Cd}, \mathrm{Pb}$, $\mathrm{Ni} \& \mathrm{Cr}$ by atomic absorption spectrophotometer (Yoshida et al., 1976).

The bacteriological analysis of the samples was performed by using Salmonella-Shigella (SS) agar, Nutrient Agar and Methylene Blue (EMB) agar. Isolation and identification of bacteria were done following the method, as outlined by Carter (1986). 
Identification of bacteria was made on the basis of colony morphology, Gram staining reaction and biochemical test. Colony characteristics were studied after 24 hours' of incubation at $37^{\circ} \mathrm{C}$. Gram's staining of the pure culture was performed according to the method described by Cheesbrough (1985). Finally the sugar fermentation test was accomplished by inoculating a loop full of NB culture into each tube containing two basic sugars of lactose and manitol separately and incubated for 24 hours at $37^{\circ} \mathrm{C}$.

\section{Results and Discussion}

Changes in physical and chemical properties during composting of SMS

The chemical changes that occur over 0 - 12 weeks were studied.There is an appreciable change in the physical and chemical properties during composting of spent mushroom substrate (Fig. 1). The $\mathrm{pH}$ of the compost showed a little change, the values being 6.62-7.11 which however indicates a change from acidic to neutral. Initial low $\mathrm{pH}$ of sample might be due to production of organic acid and incomplete oxidation of organic matter and finally increased $\mathrm{pH}$ might be due to the ammonia production during mineralization reaction (Beck-Friis, 2003; Zameer et al., 2010). The electrical conductivity (EC) was reduced drastically from 1.20 in 0 week to 0.67 in week 12 , the variation was highly significant.Warma and AngLopez (2002) reported an eventual decrease in EC which could be the effect of release of $\mathrm{Fe}^{3+} \& \mathrm{Mn}^{2+}$ ions (Zameer et al., 2010).

The $\mathrm{N}$ content of compost was increased by the end of the 12 weeks $(1.11 \% \mathrm{~N})$ in comparison with the initial value of $0.78 \% \mathrm{~N}$ at the start of the experiment. Significant decrease of organic carbon (25.3\%) was noticed in week 12 as compared to the initial value (32.9\%). As a result, considerable variations were observed in the carbon to nitrogen $(\mathrm{C} / \mathrm{N})$ ratio of compost samples which varied from 42 to 23 showing a reduced $\mathrm{C} / \mathrm{N}$ ratio at week 12 . These findings agree well with many other researchers. Warma and AngLopez (2002) has reported a $20-45 \%$ loss of carbon as $\mathrm{CO}_{2}$ during vermicomposting of municipal or industrial waste and a $42-85 \%$ increase of total $\mathrm{N}$ in vermicomposting wastes after 45 and 68 days, respectively. Organic carbon decreased due to substrate decomposition (Tajbakhsh et al., 2008) and the increase of total $\mathrm{N}$ during composting was caused by the decrease of
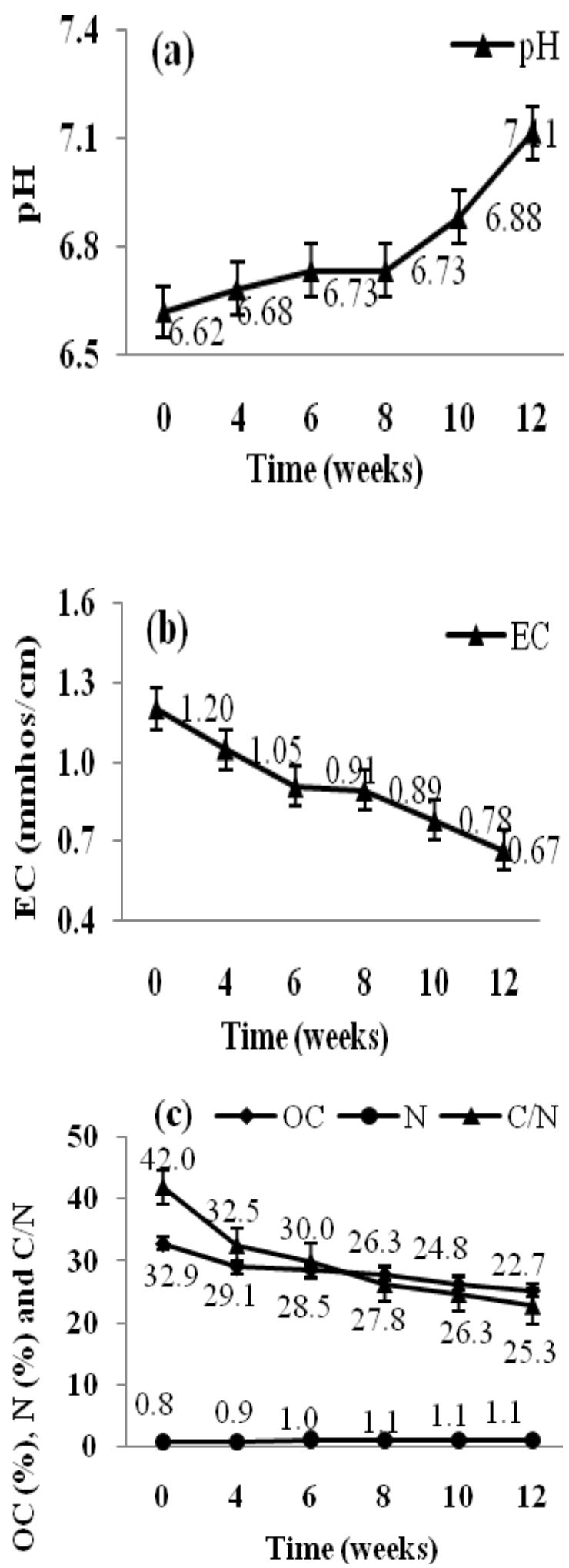

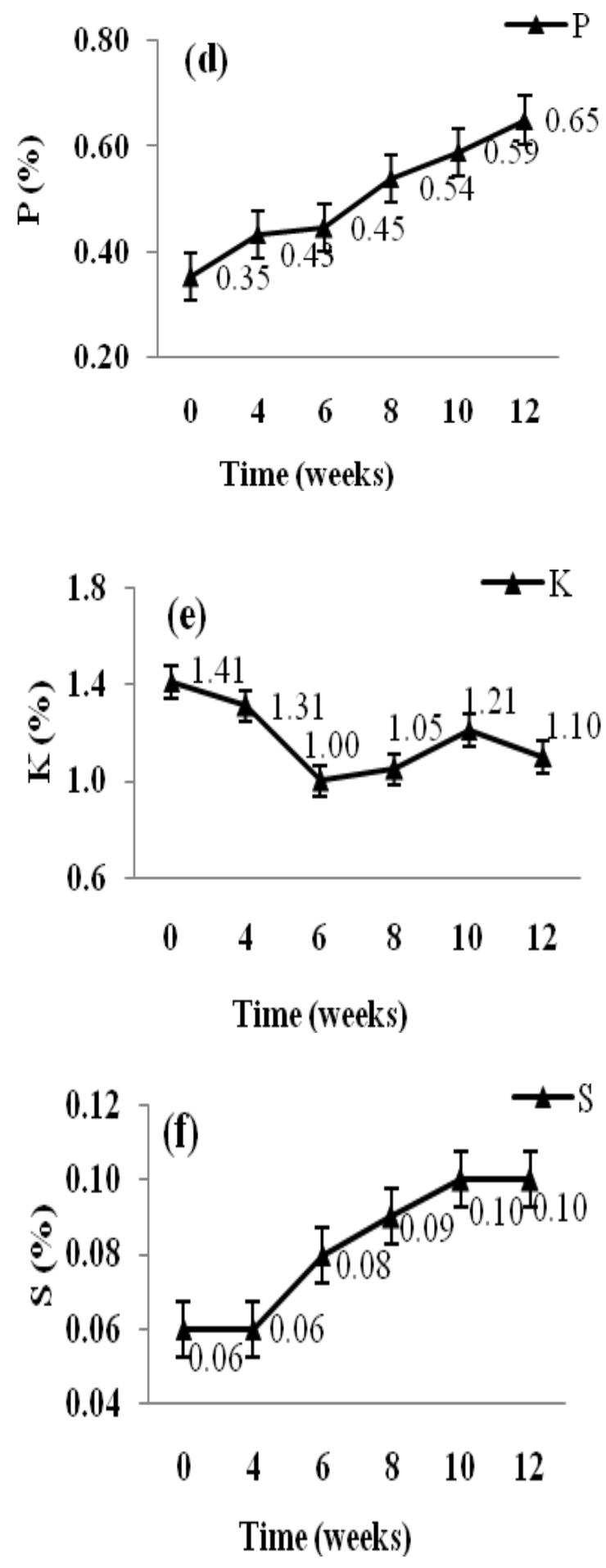

Fig. 1: Changes in chemical properties; (a) $\mathrm{pH}$, (b) $\mathrm{EC}$, (c) OC, $\mathrm{N}$ and $\mathrm{C} / \mathrm{N}$ ratio, (d) $\mathrm{P}$, (e) K and (f) $\mathrm{S}$ during composting of spent mushroom substrate

substrate carbon resulting from the loss of $\mathrm{CO}_{2}$ (Zorpar et al., 2003). The results of $\mathrm{C} / \mathrm{N}$ ratio of this study are in line with the findings of Tajbakhsh (2008) who reported a $56 \%$ decrease in $\mathrm{C} / \mathrm{N}$ ratio during 0-12 week period. In case of $\mathrm{P}, \mathrm{K}$ and $\mathrm{S}$ concentrations, total $\mathrm{P}$ content at 12 weeks' $(0.65 \%$ P) composting increased significantly compared to the initial value at 0 week composting (0.35\%). Increased $S(0.10 \%)$ and decreased K (1.10\%) content were observed in week 12 compared to initial values of S (0.06\%) and K (1.41\%), the difference being significant. Phosphorus content varied from $0.35-0.65 \%$. The variation of sulphate concentrations can be attributed to the decomposition of solid wastes (Shivakumar et al.,2004). Elango et al. (2009) reported gradually increase of phosphorous during composting process.

\section{Characteristics of the compost of spent mushroom substrate}

Indeed, for evaluation of compost quality, there is no universal standard. Several countries in Europe have produced and used their own set of standards. The Govt. of Bangladesh has promulgated a regulation entitled "Fertilizer (Management) Regulation, 2007" under the Fertilizer (Management) Act, 2006 by a Gazette Notification (SRO No. 92-Law/2007) in May 2007. To ensure the quality of organic fertilizers, maximum allowable limits (MAL) of different heavy/toxic metals have been fixed which have been published as Gazette Notification by MoA during April 2008 (FRG, 2012). In this study, quality of the compost of spent mushroom substrate was assessed by determining physical characteristics (color, odor, moisture, size reduction, weight loss and contaminants), concentrations of different nutrients and heavy metals, presence of pathogenic bacteria (E. coli and Salmonella spp) and phytotoxicity.

\section{Physical characteristics}

Compost colour as observed at maturity was blackish. There was no bad odor of finished compost (Table 1). According to Gazette Notification by the Ministry of Agriculture, Bangladesh on 02 April, 2008 (FRG, 2012), the organic fertilizer should be dark grey to black in color and odorless, with no bad smell. Moisture content of SMS compost was 27.3\% which is less than the upper limit set by recommended standards ranged between 20 and $40 \%$ 
(BSI, 2005). The upper limit of moisture content in compost is set to prevent odor problems and the development of anaerobic conditions during storage (Lasaridi et al., 2006). Composting leads to a volume reduction due to loss of carbon dioxide, water and other minor gases to the atmosphere. In the present study, size reduction and weight loss occurred by $37 \%$ and $54 \%$, respectively at the mature stage of composting. No unwanted materials, especially glass, metal and visible plastic were found in the compost.

Table 1. Physical and chemical characteristics of the compost of spent mushroom substrate

\begin{tabular}{|c|c|c|}
\hline Parameters & $\begin{array}{l}\text { Characteristics of the compost of spent mushroom } \\
\text { substrate }\end{array}$ & Recommended standards \\
\hline \multicolumn{3}{|c|}{ Physical characteristics } \\
\hline Color & Blackish & $\begin{array}{l}\text { Dark grey to black (FRG, } \\
\text { 2012) }\end{array}$ \\
\hline Odor & Earthy & $\begin{array}{l}\text { Odourless, have bad smell } \\
\text { (FRG, 2012) }\end{array}$ \\
\hline Moisture & $27.3 \%$ & $20-40 \%$ (BSI, 2005) \\
\hline Size reduction & $37 \%$ & NA \\
\hline Weight loss & $54 \%$ & NA \\
\hline Contaminants & $\begin{array}{l}\text { Free of contaminants such as glass, metal and visible } \\
\text { plastic }\end{array}$ & NA \\
\hline \multicolumn{3}{|c|}{ Nutrient concentration } \\
\hline $\mathrm{pH}$ & 7.38 & 6.9-8.3 (Bordna Mona, 2003) \\
\hline EC & 0.67 (mmhos/cm) & $\begin{array}{l}\text { 2-6 (ds/m) (Bord na Mona, } \\
2003)\end{array}$ \\
\hline $\begin{array}{l}\text { Organic carbon } \\
\text { (OC) }\end{array}$ & $24.7(\%)$ & NA \\
\hline Nitrogen $(\mathrm{N})$ & $1.17(\%)$ & 1.0-3.0 (Barker, 2009) \\
\hline $\mathrm{C}: \mathrm{N}$ ratio & $21: 1$ & $<25 \quad$ ((BSI 2005; GCST, \\
\hline Phosphorus (P) & $0.80(\%)$ & 0.4-1.1 (Bordna Mona, 2003) \\
\hline Potassium $(\mathrm{K})$ & $1.04(\%)$ & 0.6-1.7 (Bordna Mona, 2003) \\
\hline Sulphur (S) & $0.11(\%)$ & NA \\
\hline Calcium (Ca) & $2.76(\%)$ & 1.0-4.0 (Barker, 2009) \\
\hline $\begin{array}{l}\text { Magnesium } \\
\text { (Mg) }\end{array}$ & $0.43(\%)$ & 0.2-0.4 (Barker, 2009) \\
\hline Copper (Cu) & $0.001(\%)$ & 150 mg/kg (BSI, 2005) \\
\hline Iron $(\mathrm{Fe})$ & $0.51(\%)$ & NA \\
\hline Zinc (Zn) & $0.007(\%)$ & 350 mg/kg (BSI, 2005) \\
\hline $\begin{array}{l}\text { Manganese } \\
\text { (Mn) }\end{array}$ & $0.03(\%)$ & NA \\
\hline Boron (B) & $0.01(\%)$ & NA \\
\hline \multicolumn{3}{|c|}{ Heavy metal concentration } \\
\hline Cadmium (Cd) & $0.00 \mathrm{ppm}$ & 10 ppm (FRG, 2012) \\
\hline Lead $(\mathrm{Pb})$ & $0.00 \mathrm{ppm}$ & 100 ppm (FRG, 2012) \\
\hline Nickel (Ni) & $3.33 \mathrm{ppm}$ & 50 ppm (FRG, 2012) \\
\hline Cromium (Cr) & $2.31 \mathrm{ppm}$ & 500 ppm (FRG, 2012) \\
\hline
\end{tabular}

NA $=$ Not available

\section{Chemical characteristics}

Compost $\mathrm{pH}$ was near to neutral (7.38) (Table 1 which is within the recommended limit, 6.9-8.3 (Bordna Mona, 2003). One of the often used parameters to assess the rate of decomposition in the composting process is the $\mathrm{C} / \mathrm{N}$ ratio, since it can reflect the maturity of the compost (Jusoh et al., 2013). In the present study, $\mathrm{C} / \mathrm{N}$ ratio in SMS compost was found 21 , the recommended value being less than or equal to 25 (Shymala and Belagali, 2012). The concentrations of N, P, K, S, Ca and Mg 
in the SMS compost were observed as. $17 \%, 0.80 \%$, $1.04 \%, 0.11 \%, 2.76 \%$ and $0.43 \%$, respectively (Table 1). The SMS compost also contained substantial amount of Fe, Mn and B with the values of $0.51 \%$, $0.03 \%$ and $0.01 \%$, respectively. Concentrations of $\mathrm{N}$, $\mathrm{P}$ and $\mathrm{K}$ are very important to determine the quality of compost. Nitrogen concentration was in the typical range of 1.0-3.0\% (Barker, 2009). The concentrations of $\mathrm{P}, \mathrm{K}, \mathrm{Ca} \& \mathrm{Mg}$ were also found within the recommended standards (Bordna Mona, 2003) (Table 1).

The $\mathrm{Zn}$ and $\mathrm{Cu}$ contents in SMS compost were found $0.007 \%$ and $0.001 \%$, respectively which were lower than the maximum permissible concentrations (BSI, 2005; GCST, 2006). Heavy metal present in organic fertilizer may create health hazards as they may enter into human body through food chain. So, heavy metal content higher than permissible limit woulddeteriorates the quality of fertilizers. The heavy metal concentrations of $\mathrm{Cd}, \mathrm{Pb}, \mathrm{Ni} \& \mathrm{Cr}$ of SMS compost were studied and found lower than the maximum allowable limits set by Fertilizer (Management) Act, 2006 (FRG, 2012).

\section{Pathogenic bacteria (E. coli and Salmonella spp)}

In the cultural characteristic study, colony of opaque, smooth, round with black centred and metallic sheen (greenish black) was not observed on SS agar media and EMB agar media, respectively. After that, for confirmation, Gram staining and biochemical tests were performed. In Gram staining test, there was no negative reaction found. Again, no bubbles was indicated in Durham's tube which resulted no change of color of lactose and manitol sugar. Identification test confirmed the absence of pathogenic bacteria, particularly E. coli and Salmonella spp. in the final compost product. Compost requires the absence of faecal coliform bacteria (GCST, 2006) or to be less than $1000 \mathrm{cfu} \mathrm{g}^{-1}$ in compost (BSI, 2005). All compost regulations agencies suggest that Salmonella must be absent in compost intended for land application (BSI, 2005; GCST, 2006).

\section{Phytotoxicity}

Phytotoxicity test was conducted to ensure about the compost maturity or toxicity. Direct germination rates, or a modified germination index have been used as indicators of phytotoxicity in composts. After 10 days of germination, normal growth of root and seedlings were observed which indicate that SMS compost was free from phytotoxic compounds and the SMS compost attained maturity. Phytotoxicity levels almost reached zero after eight weeks of composting (Himanen and Hanninen, 2011).

\section{Conclusions}

Spent mushroom substrate (SMS) can be effectively used to produce good quality compost. The present study showed that $\mathrm{pH}$ value and the concentrations of $\mathrm{N}, \mathrm{P} \& \mathrm{~S}$ increased and the $\mathrm{EC}, \mathrm{OC}, \mathrm{C} / \mathrm{N}$ ratio decreased with the advancement of composting. Composting reduced the volume of solid waste prior to disposal. The SMS compost contains a good amount of micro and macro nutrients which are essential for plant growth. The concentration of heavy metals such as $\mathrm{Zn}, \mathrm{Cu}, \mathrm{Pb}, \mathrm{Cd}, \mathrm{Ni}$ and $\mathrm{Cr}$ was very low and were very much within the permissible limits. The SMS compost was also free of pathogenic bacteria. The SMS compost has good physical and chemical properties, with low electrical conductivity, optimal C:N ratio, optimal stability and maturity and free from pathogenic bacteria. So, it can be concluded that SMS is not just an agricultural waste but has potentiality to turn it into a good quality organic fertilizer through composting. Composting can convert mushroom waste into value added material.

\section{Acknowledgement}

The authors are grateful to the Ministry of Science and Information \& Communication Technology (MSICT), the People's Republic of Bangladesh for supporting by a research grant through a scholarship to the first author R. Ashrafi for higher studies leading to the $\mathrm{PhD}$ degree. Authors are also thankful to the Department of Soil Science, Bangladesh Agricultural University, Mymensingh for providing necessary facilities to carry out this study.

\section{References}

Barker AV (2009). Composition and uses of compost, Agricultural uses of bi-products 
and wastes. ASC symposium series. American Chemical Society, 668: 140-162.

Beck-Friis SS, Jonsson H, Eklind Y, Kirchmann H, (2003). Composting of source-separated household organics at different oxygen levels: Gaining an understanding of the emission dynamics. Compost Science \& Utilization, 11(1): 41-50.

Bordna M (2003 Compost testing and analysis service-Interpretation of results. available from Bordna Mona, Newbridge. Co. Kildare.

BSI PAS, 100 (2005). Specification for composted materials. British Standards Institute, London, ISBN-10: 0580405907.

Carter GR (1986). Studies on Pasteurella multocida. A hemagglutination test for the identification of serological types. Journal of Veterinary Research, 16: 481-184.

Chapman CA, Pratt PF (1964). Methods of Analysis for Soil, Plant and Water. Division of Agricultural Science, University of California, USA.

Cheesbrough M (1985). Medical laboratory manual for tropical countries. Microbiology ( $1^{\text {st }}$ edi.). English Language Book Society, London. pp. 400-480.

Elango D, Thinakaran N, Panneerselvam P, Sivanesan S (2009). Thermophilic composting of municipal solid waste. Applied Energy, 86(5): 663-668.

Fathi H, Zangane A, Fathi H, Moradi H, (2014). Municipal solid waste characterization and it is assessment for potential compost production: A case study in Zanjan city, Iran. American journal of Agriculture and Forestry, 2(2): 39-44.

FRG (Fertilizer Recommendation Guide) (2012). Bangladesh Agricultural Research Council (BARC), Farmgate, Dhaka1215. 274p.

GCST Gulf Countries Standards, (2006). Standards of fertilizers and soil conditioners in Gulf Countries.Retrievedfrom http://www.moa. gov.-sa/public/portal on 26 January, 2012.

Hai FI, MA Ali (2005). A study on solid waste management system of Dhaka city corporation: Effect of composting and landfill location. UAP Journal of Civil and Environmental Engineering, 1(1): 18-26.

Himanen M, Hanninen K (2011). Composting of biowaste, aerobic and anaerobic sludges: Effect of feedstock on the process and quality of compost. Bioresour. Technol., 102(3): 2842-2852.

Irshad M, Eneji AE, Hussain Z, Ashraf M (2013). Chemical characterization of fresh and composted livestock manures. Journal of Soil Science and Plant Nutrition, 13(1): 115-121.

Jackson ML, (1973). Soil Chemical Analysis. Prentice Hall of India, Private Limited, New Delhi, India.

Jusoh MLC, Manaf LA, Latiff PA (2013). Composting of rice straw with effective microorganisms (EM) and its influence on compost quality. Iranian Joural of Environmental Health Science \& Engineering,10: 17. (doi:10.1186/17352746-10-17)

Lasaridi K, Loanna P, Kotsou M, Georg P, Thakis M (2006). Quality assessment of compost in the Greek market: the need for standards and quality assurance. Journal of Environmental Management, 80(1): 58-65.

Medina E, Paredes C, Bustamante MA, Moral R, Moreno-Caselles J, (2012). Relationships between soil physic-chemical, chemical and biological properties in a soil amended with spent mushroom substrate. Geoderma, 173174: 152-161.

Nair J, Sekiozoic V, Anda M (2006). Effect of precomposting on vermicomposting of kitchen waste. Bioresour. Technol., 97(16): 20912095.

Page AL, Miller RH, Keeney DR (1982). In Methods of Soil Analysis, Part2: Chemical and Microbiological Properties. $2^{\text {nd }}$ Ed. SSSA, Madison, Wisconsin.

Ranalli G, Botturea G, Taddei P, Garavni M, Marchetti R, Sorlini G (2001). Composting of solid and sludge residues from agricultural and food industries, bioindicators of monitoring and compost 
maturing. Journal of Environmental Science and Health, 36(4): 415-436.

Shivakumar BS, Thandaveswara, Chandarasekaran KD, (2004). Solid waste leachate quality \& its effects on soil properties. Pollution Research, 23(1): 179-182.

Shymala DC, Belagali SL (2012). Studies on variations in physico-chemical and biological characteristics at different maturity stages of municipal solid waste compost. International Journal of Environmental Sciences, 2(4): 1984-1997.

Tajbakhsh J, Abdoli MA, Goltapeh EM, Alahdadi I, Malakouti MJ (2008). Trend of physicchemical properties changes in recycling spent mushroom compost through vermicomposting by epigeic earthworms Eiseniafoetida and E. Andrei. Journal of Agricultural Technology, 4(2): 185-198.

Topas A, Demierege S, Ayan EM, Yanik J (2014). Spent mushroom compost as biosorbent for dye biosorption. Clean-Soil, Air, Water, 42(9999): 1-8.

Warma PR, AngLopez MJ (2002). The chemical properties of vermicompost derived from different feed stocks. In: Proc Intl Composting and Compost SciSimposium, Columbus, Ohio, CD Rom.

Yang Y, Huang C, Hu K, (2015). Purification and further characterizations of the cellulose from the spent mushroom compost of Hypsizygusmarmoreus. Research Journal of Biotechnology, 120(2): 52-57.

Yoshida SD, Forno A, Cock JH, Gomez KA, (1976). Laboratory Manual for Physiological Studies of Rice. 3rd edition, International Rice Research Institutuion, Manila, Philippines. pp. 14-22.

Zameer F, Meghashri S, Gopal S Rao BR (2010). Chemical and microbial dynamics during composting of herbal pharmaceutical industrial waste. E-Journal of Chemistry. 7(1): 143-148.

Zorpas AA, Arapoglou D, Panagiotis K (2003). Waste paper and clinoptilolite as bulking material with dewatered an aerobically stabilized promary sewage sludge (DASPSS) for compost production. Waste Manage, 23(1): 27-35. 